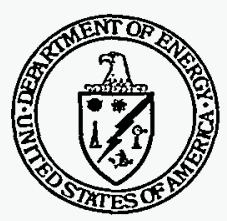

\title{
The PCB Mark
}

BACKGROUND: Polychlorinated biphenyls (PCBs) are a class of organic chemicals that had become widely used in industrial applications due to their practical physical and chemical properties. Historical uses of PCBs include dielectric fluids (used in utility transformers, capacitors, etc.), hydraulic fluids, and other applications requiring stable, fire-retardant materials. Due to findings that PCBs may cause adverse health effects and due to their persistence and accumulation in the environment, the Toxic Substances Control Act (TSCA), enacted on October 11, 1976, banned the manufacture of PCBs after 1978 [Section 6(e)]. The first PCB regulations, promulgated at 40 CFR Part 761, were finalized on February 17, 1978. These $P C B$ regulations include requirements specifying disposal methods and marking (labeling) procedures, and controlling PCB use. To assist the Department of Energy (DOE) in its efforts to comply with the TSCA statute and implementing regulations, the Office of Environmental Guidance has prepared the document "Guidance on the Management of Polychlorinated Biphenyls (PCBS)." That document explains the requirements specified in the statute and regulations for managing PCBs including PCB use, storage, transport, and disposal.

The requirements outlined at 40 CFR 761.40 through 761.45 specify marking requirements for most PCB Items (i.e, any PCB Article, PCB Container, PCB Article Container, or PCB Equipment that contains $\mathrm{PCBs}$ ). Most $\mathrm{PCB}$ ltems require $\mathrm{PCB}$ marks, which are defined as a descriptive name, instructions, cautions, or other information applied to $P C B$ Items or other objects subject to these regulations. The marking regulations include requirements for PCB marks on PCB Items, storage areas, and temporary storage areas. This Information Brief supplements the PCB guidance document by responding to common questions concerning marking requirements for PCBs. It is one of a series of Information Briefs pertinent to PCB management issues.

STATUTE: $\quad$ Toxic Substances Control Act of 1976 (TSCA)

REGULATION: $\quad 40$ CFR Part 761

REFERENCES: 1. "Guidance on the Management of Polychlorinated Biphenyls (PCBs)," Environmental Guidance Manual, DOE Office of Environmental Guidance, RCRA/CERCLA Division (EH-231), DOE/EH-0350, June 1993.

2. "РCB Storage Requirements," EH-231 TSCA Information Brief, EH-231-060/1294, Office of Environmental Guidance, RCRAJCERCLA Division, December 1994.

3. "Disposal Requirements for PCB Waste," EH-231 TSCA Information Brief, EH-231-056/1294, Office of Environmental Guidance, RCRA/CERCLA Division, December 1994.

\section{What is a PCB mark and what does it look like?}

The PCB mark (see Figure 1) is a label with black striping around the border and containing certain information specified in the regulations that is applied to PCB Items (i.e., any manufactured item containing or contaminated with PCBs). There are two marks, Mark $M_{L}$ and Mark $M_{S}$; the only difference between the two is the size of the mark. PCB Mark $M_{L}$ is a 6" $\times 6$ " square; PCB Mark $M_{s}$ is a 1" $\times 2$ " rectangle. The text of the mark includes the warning "Caution Contains PCBs," instructions in case of accident or spill, and the telephone number of the National Response Center. The PCB mark must have either a yellow or white background.

\section{Where is the PCB mark required to be attached?}

The mark must be placed in a prominent position on the exterior of a PCB Item so that it can be easily read. The mark must also be sufficiently durable to equal or exceed the life of the PCB Item. If Mark $M_{L}$ is too large for the item, it may be proportionally reduced in size to a minimum of 2 " $\times 2$ ". If a mark smaller than 2" $\times 2$ "is required, Mark $M_{s}$ may be used. If $M$ ark $M_{s}$ is too large, it may be reduced in size proportionally to a minimum size of $1 \mathrm{~cm} \mathrm{x} 2 \mathrm{~cm}$. Both marks are commercially available from vendors of industrial placarding and health and safety supplies. 


\section{What types of items require marking?}

Most PCB Items, including PCB containers, that have a PCB concentration of $\geq 50$ ppm must be marked. There are two exceptions to this requirement: (1) transformers with a PCB concentration of $<500 \mathrm{ppm}$ do not require marking and (2) PCB Large High-Voltage Capacitors (i.e., capacitors that contain $\geq 3$ pounds of dielectric fluid and operate at or above 2,000 volts) do not require marking if: (a) they are installed in a protected location, such as on a power pole, in a structure, or behind a fence, and (b) the power pole, structure, or fence is marked. Additionally, a record identifying PCB Large High-Voltage Capacitors must be maintained at the protected location.

Some items must be marked even if they contain $<50 \mathrm{ppm}$ PCB (i.e., compressors or natural gas pipelines). Certain items must also be labelled "no PCBs" if they do not contain PCBs. These items include Large Low-Voltage Capacitors (i.e., capacitors that contain $\geq 3$ pounds of dielectric fluid and operate below 2,000 volts) and Small Capacitors (i.e., capacitors that contain $<3$ pounds of dielectric fluid and normally are used in alternating current circuits and fluorescent light ballasts manufactured after July 1, 1978).

Any unmarked PCB Items must be marked as soon as possible after they are discovered.

\section{What are the marking requirements for areas where PCB Items are located?}

The PCB Mark $M_{L}$ should be displayed in a prominent position at each point of access to a PCB storage area (see reference \#2). In addition, the means of access to transformer locations containing one or more PCB Transformers must be marked with Mark $M_{L}$. PCB transport vehicles also must be marked on each end and each side with Mark $M_{L}$ if they are being used to transport either (1) $>45 \mathrm{~kg}$ of liquid PCBs at a concentration of $\geq 50 \mathrm{ppm}$ or (2) 1 or more PCB Transformers defined as having a PCB concentration of $\geq 500 \mathrm{ppm}$.

\section{Are there any other labeling requirements?}

Yes. In addition to applying the PCB mark to the required $\mathrm{PCB}$ and $\mathrm{PCB}$ Items, $\mathrm{PCB}$ wastes in storage for disposal must also be labeled with a notation indicating the date that the item was removed from service for disposal. If the wastes in storage include drums of PCB-contaminated soil from a remediation activity, the "date removed from service for disposal" would be the date on which the soil was excavated and placed into drums. If the wastes are liquid wastes, such as solvents used for flushing or decontaminating PCB Items, the "date removed from service for disposal" is defined as the date that the first batch went into the drum.

If PCBs in containers or PCB Items are contaminated with hazardous wastes regulated under the authority of the Resource Conservation and Recovery Act (RCRA), they must be marked in accordance with the applicable RCRA hazardous waste marking requirements, as defined in 40 CFR Part 262, as well as with the applicable TSCA marking requirements.

Figure 1 - Mark $M_{L}$

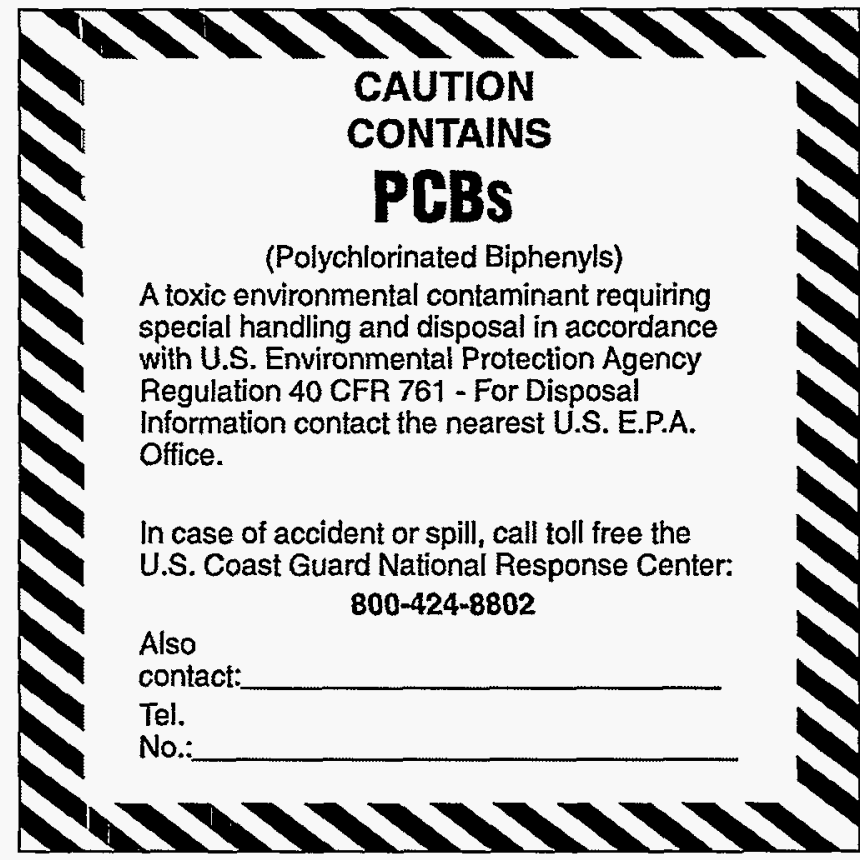

Questions of policy or questions requiring policy decisions will not be addressed in EH-231 Information Briefs unless that policy has already been established through appropriate documentation. Please refer any questions concerning the subject material covered in this Information Brief to Carolyn Thompson Walder, RCRA/CERCLA Division, EH-231, (202) 586-8248. 


\section{DISCLAIMER}

This report was prepared as an account of work sponsored by an agency of the United States Government. Neither the United States Government nor any agency thereof, nor any of their employees, make any warranty, express or implied, or assumes any legal liability or responsibility for the accuracy, completeness, or usefulness of any information, apparatus, product, or process disclosed, or represents that its use would not infringe privately owned rights. Reference herein to any specific commercial product, process, or service by trade name, trademark, manufacturer, or otherwise does not necessarily constitute or imply its endorsement, recommendation, or favoring by the United States Government or any agency thereof. The views and opinions of authors expressed herein do not necessarily state or reflect those of the United States Government or any agency thereof. 


\section{DISCLAIMER}

Portions of this document may be illegible in electronic image products. Images are produced from the best available original document. 